\title{
Readers and Consumers of Popular Print
}

\author{
Shanti Graheli | ORCID 0000-0001-7183-0886 \\ Lecturer in Comparative Literature, University of Glasgow, Glasgow, \\ Scotland \\ shanti.graheli@glasgow.ac.uk
}

\begin{abstract}
This article explores the theoretical strands and methodological possibilities for the study of the consumption of popular print in the pre-modern age. The first section explores general approaches and cross-disciplinary angles to the field. The second section looks at core methodologies in approaching the multi-faceted issue of consumption of popular print. The third section offers a comparative discussion of pan-European themes, including literacy and schooling, the sociality of reading and consumption, the weight of restrictions and emancipation in regulating access to print, and the materialities of consumption as a physical, multisensory experience.
\end{abstract}

\section{Keywords}

consumption - readers - literacy - materiality - orality

The history of reading has been attracting increasingly more scholarly attention, in an attempt to recapture the reading experience across society. ${ }^{1}$ Research focus has gradually shifted to include the 'common reader' alongside illustrious readers, already the concern of reception and provenance studies, so to understand the impact of the history of reading on societal change and identity building across Europe. A systematic study of the consumption of popular print in early modern Europe would require a comparative investigation on

1 Many thanks to those who commented on papers and early drafts of this work: Susan Bassnett, Jacob Baxter, Laura Carnelos, Matthew Grenby, Nina Lamal, Elisa Marazzi, Henriette Partzsch, Jeroen Salman and Arthur der Weduwen. Any mistakes remain my own responsibility. All links were last accessed on o1/11/2020. 
several levels, including time, space, languages, genres, genders, age of readers, literacy levels and typologies of sources. Any enquiry aiming to be comprehensive must necessarily cross-reference perspectives in the history of reading in general, and the consumption of texts by particular groups of readers, with the understanding of popular print as a sub-category that is governed by distinct patterns of documentation, preservation, reception and transmission, as well as looking at separate nations of readers as they were investigated within a monolingual environment or in less common translingual studies. This piece makes a start at bringing together these three strands under a comparative investigative framework.

Under the broad category of 'consumption' I include the non-mutually exclusive combination of the ownership, borrowing and lending of printed (and sometimes handwritten) texts, exposure to print in the public sphere, individual and collective reading practices, silent and loud, performed or heard, extensive, intensive, selective or fleeting, as well as both textual and non-textual uses. Throughout the pre-modern age, the consumption of popular print was a pervasive phenomenon across all of society. Indeed, because of its accessibility by all groups of readers and consumers, the expression 'literatures of wide dissemination' offers a more suitable descriptor for our corpus from the interpretive angle of consumption. Many readers who read popular print texts also read other types of books; equally, many readers who read some texts within our corpus had no interest in others. In some areas and for many genres, printed text alone does not suffice to describe patterns of consumption; some popular texts circulated primarily in handwritten form well after the advent of print while others may be better represented by iconographic materials rather than text. In all areas, reading alone does not suffice to describe the phenomenon of consumption; trends in consumption are best represented as an inter-medial, cross-sensory experience. It is therefore important that we do not isolate artificially the consumption of popular print alone, but that it is contextualised within the general question of reading and using books in the pre-modern age.

This contribution builds upon existing scholarship that has explored some of these themes - often pioneering whole new fields of enquiry - in proposing some broad-strokes observations on the uses of popular print in early modern Europe as well as avenues for further investigation. The considerations drawn here are necessarily limited in length and scope, and conditioned by my own interests, languages and areas of expertise, but it is hoped that this piece might prompt further reflections and enquiries. The article is divided into three main sections. Section 1 offers an overview of general disciplinary and theoretical approaches to investigate the consumption of popular print. Section 2 
considers key typologies of sources used by scholars and aims to showcase possible access points into our topic. Section 3 explores recurrent patterns in the early modern European consumption of popular print.

\section{General Approaches, Disciplinary Crossroads}

The investigation of books as material objects and the reconfiguration of bibliography as 'the study of the sociology of texts', famously advocated by Don McKenzie during the inaugural cycle of the Panizzi lectures in 1985, bolstered the appreciation of readers and their history. ${ }^{2}$ Roger Chartier further emphasised the importance of consumption and reception in any interpretive framework preoccupied with books and their history, stating that:

There is no text apart from the physical support that offers it for reading (or hearing), hence there is no comprehension of any written piece that does not at least in part depend upon the forms in which it reaches the reader. ${ }^{3}$

Chartier's approach to the history of texts was established from the start as the understanding of their materiality; his first monograph-length study had investigated the history of education in early modern France, thus exploring the consumption of print through the question of literacy across society. ${ }^{4}$

The study of literacy and its diverse modes and manifestations needs be at the forefront of any investigation into the uses of the book, as it accounts for differences based on geography, social status, gender, age, confession, and language. Such studies often take into account popular print as it includes the most widely accessible and affordable categories of reading material (cheap devotional texts, ballads, chapbooks or almanacs), offering insights into the experience of readers and reading practices across the full spectrum of literacy and society. ${ }^{5}$ The spread of cheaper books is now acknowledged as having supported the rise in literacy levels. But the importance of popular print

2 D.F. McKenzie, Bibliography and the Sociology of Texts (London 1986), p. 5 .

3 R. Chartier, The Order of Books: Readers, Authors, and Libraries in Europe between the Fourteenth and Eighteenth Centuries, transl. L.G. Cochrane (Cambridge 1994), p. 9.

4 R. Chartier, D. Julia \& M.M. Compère, L'éducation en France du XVIe au XVIIIe siècle (Paris 1976).

5 P. Burke, Popular Culture in Early Modern Europe (New York 1978); R.A. Houston, Literacy in Early Modern Europe (2nd ed., Harlow 2002); D. Vincent, The Rise of Mass Literacy: Reading and Writing in Modern Europe (Cambridge 200o). 
and its modes of consumption can be pushed further. In discussing literacy across early modern Europe, Rab Houston pointed out that it was not enough to acquire the appropriate skills, but that these had to be exercised in order to be retained. ${ }^{6}$ In analysing signatures on notarial acts, the traditional means for assessing literacy in the past, historians have remarked upon the decay of literacy over time. The aging population lost the ability to write or even to hold a pen through lack of practice. ${ }^{7}$ If we accept that the same was likely the case with the ability to read, cheap and popular print would have served the allimportant purpose of fostering and supporting dwindling literacy by incentivising the act of reading.

Exposure to print was also crucial to the retention of literacy, hence the exception in Houston's findings that identifies household servants as becoming more literate with age. Roger Chartier, Rosa Salzberg, Filippo De Vivo, Antonio Castillo Gomez and others have highlighted the role of the urban settings as catalysers of literacy, thanks to the ubiquity of print in the cityscape, and specific roles such as that of the town crier, devised to bridge the gap between literate and illiterate. ${ }^{8}$ Their approach brings together the history of the book with studies in material and oral culture, urban history and the study of state bureaucracy, both in the context of early modern Europe and in areas of European colonisation such as Mexico, Peru and others. Similarly, genres such as the execution ballads indicate how print, oral culture and performance were deeply intertwined in civic life in the early modern period. ${ }^{9}$

The external environment was not the only element of materiality influencing the reading experience. Theorist of reading Karin Littau has argued that in exploring the question of consumption, materiality as a framework should be applied not only to the book or text, but also to the reader; not only to the external material circumstances in which the reader finds him or herself, but the internal state of the reader. The body of the text and the body of the reader alike should be investigated if we want to understand the multifaceted idea

6 Houston, op. cit. (n. 5), p. 156.

7 Houston, op. cit. (n. 5), pp. 155-6.

8 R. Chartier, The Cultural Uses of Print in Early Modern France (Princeton 1987); F. De Vivo, Information and Communication in Venice: Rethinking Early Modern Politics (Oxford 2007); R. Salzberg, Ephemeral City: Cheap Print and Urban Culture in Renaissance Venice (Manchester 2016); A. Castillo Gomez, 'Writings on the Streets: Ephemeral Texts and Public Space in the Early Modern Hispanic World', in: Approaches to the History of Written Culture: A World Inscribed, ed. M. Lyons \& R. Marquilhas (Cham 2017), pp. 73-96.

9 U. McIlvenna, S.G. Brandtzæg \& J. Gomis Coloma, 'Singing the News of Punishment: The Execution Ballad in Europe, 1550-19oo', this issue, pp. 123-159. 
of the consumption of text. ${ }^{10}$ Littau links this specifically to Rolf Engelsing's 'Leserevolution' in the approach to popular entertainment texts, where the concept of 'consumption' is seen as integral to the idea of reading fleetingly but extensively (as opposed to intensively). ${ }^{11}$ This corresponded to a fever for reading - as described by a contemporary metaphor - that could only take hold of the reading public through the increased availability and affordability of popular print.

The effort of recovering the individuality of readers has frequently been inspired by studies of modern and contemporary reading, and the methodological possibilities suggested therein. Janice Radway's seminal study of women as consumers of popular romantic fiction (1984), based on interviews with readers exploring their reading motives, habits and rewards, is a case in point. ${ }^{12}$ This is what scholars have been trying to recreate for the study of readers and their practices in early modern Europe, by investigating egodocuments such as diaries, letters and reading marks, essentially trying to get the readers themselves to 'reveal' their story. ${ }^{13}$ Studies by Martyn Lyons and Jonathan Rose in this area have both concluded that the history of reading is also deeply intertwined with the history of writing practices. ${ }^{14}$ The methodological framework termed by Lyons as the 'new history from below' was fruitfully applied to other contexts; one such example draws together the testimonies from autobiographies from the Nordic European communities. ${ }^{15}$

For the earlier centuries, characterised by lower literacy rates and scanter sources, pioneering work is being done through the systematic and comparative investigation of readers' marks across a given corpus. ${ }^{16}$ Recent approaches

10 K. Littau, Theories of Reading: Books, Bodies, and Bibliomania (Cambridge and Malden 2006), p. 25.

11 Littau, op. cit. (n. 10), pp. 39-42.

12 J.A. Radway, Reading the Romance: Women, Patriarchy, and Popular Literature (Chapel Hill and London 2009).

13 Critical discussions of this turn in the discipline include S. Colclough, 'Readers', in: A Companion to the History of the Book, ed. S. Eliot (Oxford 2008), pp. 51-62; I. Jackson, 'Approaches to the History of Readers and Reading in Eighteenth-Century Britain', The Historical Journal, 47.4 (2004), pp. 1041-54.

14 M. Lyons, A History of Reading and Writing in the Western World (Basingstoke 2009); M. Lyons, The Writing Culture of Ordinary People in Europe, c.1860-1920 (Cambridge 2012); M. Lyons, Reading Culture \& Writing Practices in Nineteenth-Century France (Toronto 2016); J. Rose, The Intellectual Life of the British Working Classes (2nd rev. ed., New Haven 2010).

15 White Field, Black Seed: Nordic Literacy Practices in the Long Nineteenth Century, ed. A. Kuismin \& M.J. Driscoll (Helsinki 2013).

16 For example, W.H. Sherman, Used Books: Marking Readers in Renaissance England (Philadelphia 2008). 
in book history have extended this area of investigation to include fragments and waste materials, cuttings and scrapbooks as reading practices. ${ }^{17}$ Partnership and exchange are a frequent feature in this field, which is so often advanced by collective volumes. ${ }^{18}$ Major collaborative projects include EDITEF - L'édition italienne dans l'espace francophone à la première modernité, directed by Chiara Lastraioli and MEI - Material Evidence in Incunabula, led by Cristina Dondi. ${ }^{19}$ The digital age has catalysed new channels for collaboration. Primary sources collected via the Twitter hashtag \#herbook, devised by Mark Empey, and the detailed blog posts in Early Modern Female Book Ownership. \#herbook, led by Martine van Elk, are exemplary in this context for sharing and disseminating evidence of women as readers. ${ }^{20}$

As these projects focus especially on marks in books, certain practices of consumption cannot be fully represented - and this is particularly the case with popular print. The study of literacy shows that books and printing alone give a very partial view of readers and consumers of books, with orality and aurality playing an essential part within that equation. While this fact has long being acknowledged, the challenge is recovering evidence of these practices. Important work in this context has been done by Brian Richardson and Jennifer Richards, respectively trying to recover the 'lost voices' of early modern Italy and England. ${ }^{21}$ Richardson's team-led project Italian Voices (2007-2013) highlighted the importance of spoken and sung words to the transmission of textual cultures; several strands of that research are recalled throughout this piece. ${ }^{22}$ While we are far from achieving the same level of depth across the European popular print corpus, these studies set the scholarly agenda for future investigations.

17 The Renaissance Collage: Toward a New History of Reading, ed. J. Fleming, W. Sherman \& A. Smyth, Journal of Medieval and Early Modern Studies (2015).

18 For example, Owners, Annotators and the Signs of Reading, ed. R. Myers, M. Harris \& G. Mandelbrote (New Castle, DE and London 2005).

19 EDITEF: http://www.editef.univ-tours.fr; MEI: https://www.cerl.org/resources/mei/main.

20 https://earlymodernfemalebookownership.wordpress.com, run by Mark Empey, Sarah Lindenbaum, Tara Lyons, Erin McCarthy, Micheline White, Georgianna Ziegler and Martine van Elk.

21 J. Richards, Voices and Books in the English Renaissance: A New History of Reading (Oxford 2019).

22 https://italianvoices.leeds.ac.uk. 


\section{Methodologies and Sources}

\section{The Archaeology of Reading}

The investigation of reading and uses of the book in the early modern age has a privileged source in the material evidence displayed in and by extant copies. A material approach that works to establish the 'archaeology of reading', borrowing the expression by Anthony Grafton and Lisa Jardine, is therefore a key method to investigate the consumption of popular print. ${ }^{23}$

The material investigation of copy-related features in early modern books includes the recording and analysis of (1) textual or graphic marks of use in the copy and (2) marks of use that are neither verbal nor graphic. The first category may include signatures, ex-libris or statements of ownership of the book, gift notes, annotations and inscriptions (related to the textual content of the book or not), doodles or colouring of existing illustrations, navigational marks to facilitate the use of the copy such as handwritten pagination or foliation, indexing and rubrication, pen trials and scribbles, among others. The second category may include folding marks, dirt, cropped margins, missing leaves or passages, as well as the general state of preservation of the copy. The bookbinding with its constitutive elements is placed somewhere in between the two categories; it may feature generic decoration or identifiable elements related to the individual library or manufacturing workshop as either or both verbal and graphic marks (e.g. initials, names, dates, or mottoes either in writing or tooling, coats of arms, titling, topographic information such as the pressmark, etc) as well as being formed entirely of marks that are neither verbal nor graphic (e.g. the cover being simply a wrapper or an archival binding). ${ }^{24}$ The analysis of such marks has been traditionally applied to early materials but can be just as fruitful in exploring modern readers, as Heather Jackson has aptly demonstrated. ${ }^{25}$

The typologies of marks in books are universal, but the likelihood of finding any such marks is subject to a genre-based distinction, and to some extent influenced by form. In literary studies, scholars apply genre theory to express the expectation of what patterns may be found in normative texts within a certain group. The study of the consumption of texts is ruled by similar principles. Not all early modern books lent themselves to being thoroughly annotated.

23 The Archaeology of Reading, https://archaeologyofreading.org.

24 J. Miller, Books Will Speak Plain: A Handbook for Identifying and Describing Historical Bindings (Ann Arbor, MI 2010); D. Pearson, Provenance Research in Book History: A Handbook (rev. ed., Oxford/New Castle, DE 2019).

25 H.J. Jackson, Marginalia: Readers Writing in Books (New Haven/London 2001). 


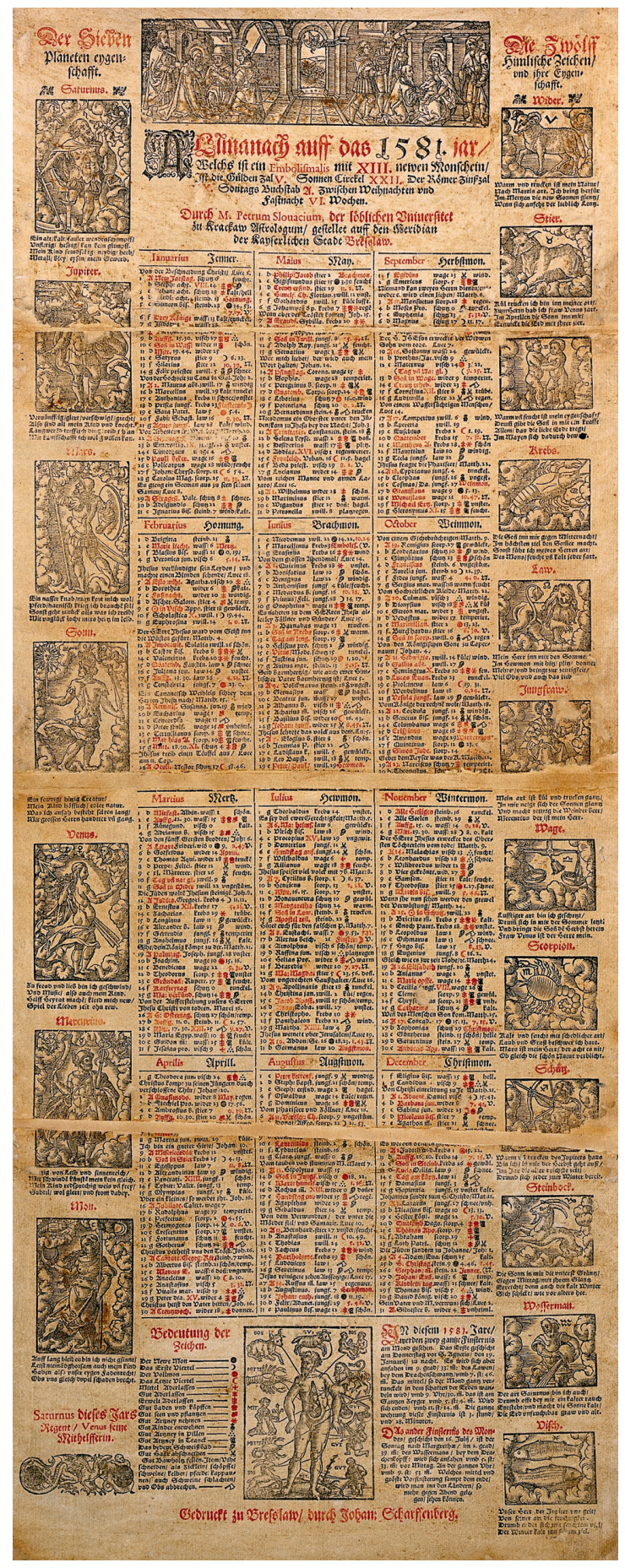

FIGURE 1

Almanac with fold marks

Petrus Slovacius, Allmanach

auff das 1581 jar (Breslau: Johan

Scharffenberg, [1580])

CREDIT: SLOVACIUS, PETRUS.

ALLMANACH AUFF DAS

1581. CREDIT: WELLCOME

COLLECTION. ATTRIBUTION 4.0

INTERNATIONAL (CC BY 4.0) 
This was and still is the case for much popular print. For example, entertainment literature as a genre was meant for fast reading rather than slow rumination (think Game of Thrones or Sophie Kinsella's Shopaholic series in our day). It seems that only rarely did readers annotate such texts; we may find the exception, but it ought to be framed as such. Functional texts, such as recipe books, almanacs, or herbals were more likely to be annotated. Volumes in these categories often feature annotations to the table of contents, including aids to improve the recoverability of information or comments on the validity of a particular section. Larger books that were likely read at a desk would have a higher chance of explicit reading marks than smaller items that were possibly read in the street, in a public space, for performative purposes, or during leisure time. On the other hand, the latter category was more likely to feature non-verbal and non-graphic marks, such as folding marks or dirt, and was more prone to be used outside the home environment. In other words, form and genre are indicative of expected uses, if not always of the actual uses of texts.

Similarly, language may offer clues as to the intended readership of popular print, in the absence of more direct evidence - especially where minority languages and dialects are concerned. Niall Ó Ciosáin has demonstrated that Ireland, Scotland, Wales and Brittany all fostered a sustained readership for popular print in the minority Celtic languages, interested in devotional texts, almanacs, songs on current affairs and traditional ballads. ${ }^{26}$ In studying patterns of consumption of popular print specifically we encounter the additional difficulty posed by their defining material features. Narrow margins and thin paper often made texts in our corpus quite unsuitable for extensive annotations. ${ }^{27}$ The exception is represented by schoolbooks, which were often produced with a large interlinear space under the expectation that readers would wish to take punctual notes about the text's content.

Much of our first-hand knowledge on the uses of popular print - as well as elements related to production and distribution - rests upon the collecting efforts of exceptional readers such as Pierre L'Estoile, Samuel Pepys, or Hernando Colón. These readers are not representative of general reading and collecting practices; but their unusual habits have allowed for the preservation of much that would otherwise have been lost. This is particularly the case with collective volumes of contemporary ephemeral materials that have been preserved thanks to the efforts of such readers.

26 N. Ó Ciosáin, 'Popular Print in Unofficial Languages: Ireland, Scotland, Wales, and Brittany', in: Crossing Borders, Crossing Cultures: Popular Print in Europe (1450-1900), ed. M. Rospocher, J. Salman \& H. Salmi (Berlin/Boston 2019), pp. 199-214.

27 See L. Carnelos, 'Popular Print under the Press: Strategies, Practises and Materials', this issue, pp. ${ }^{8-} 35$. 


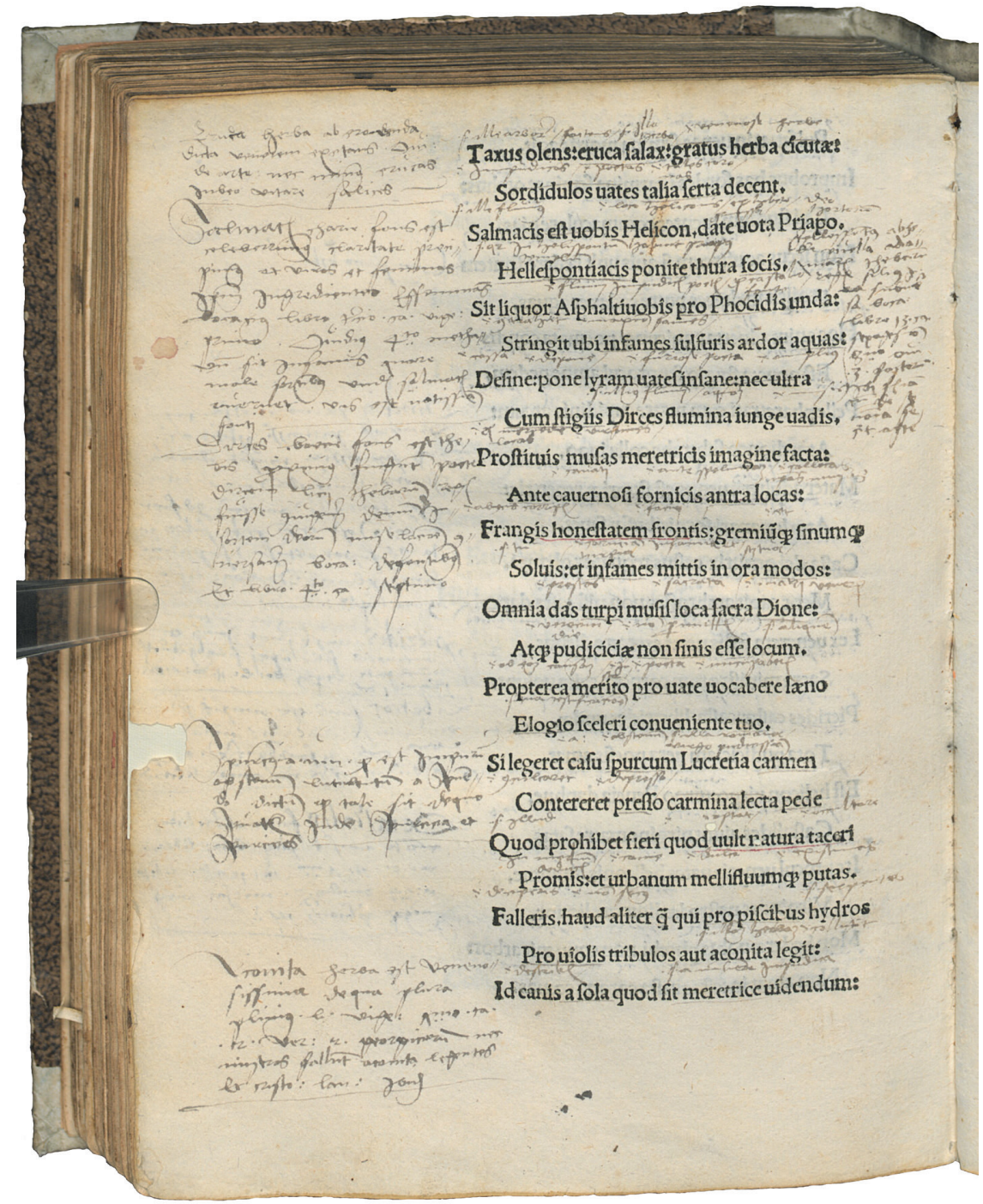

FIGURE 2 Books for students: writing between the lines Battista Spagnoli, Contra poetas impudice loquentes (Wien: [Johann Winterburger], 1500) MUNICH, BAYERISCHE STAATSBIBLIOTHEK. BSB-INK B-40. URN:NBN:DE:BVB:12-BSBO0005999-9

Contemporary or near-contemporary Sammelbände (Italian: miscellanee; French: recueils factices; Dutch: convoluut; English: bound-with) offer unparalleled depth of detail, both by indicating the context of reading (e.g. what texts were read together, what was the general profile of the copy and of the reader), 


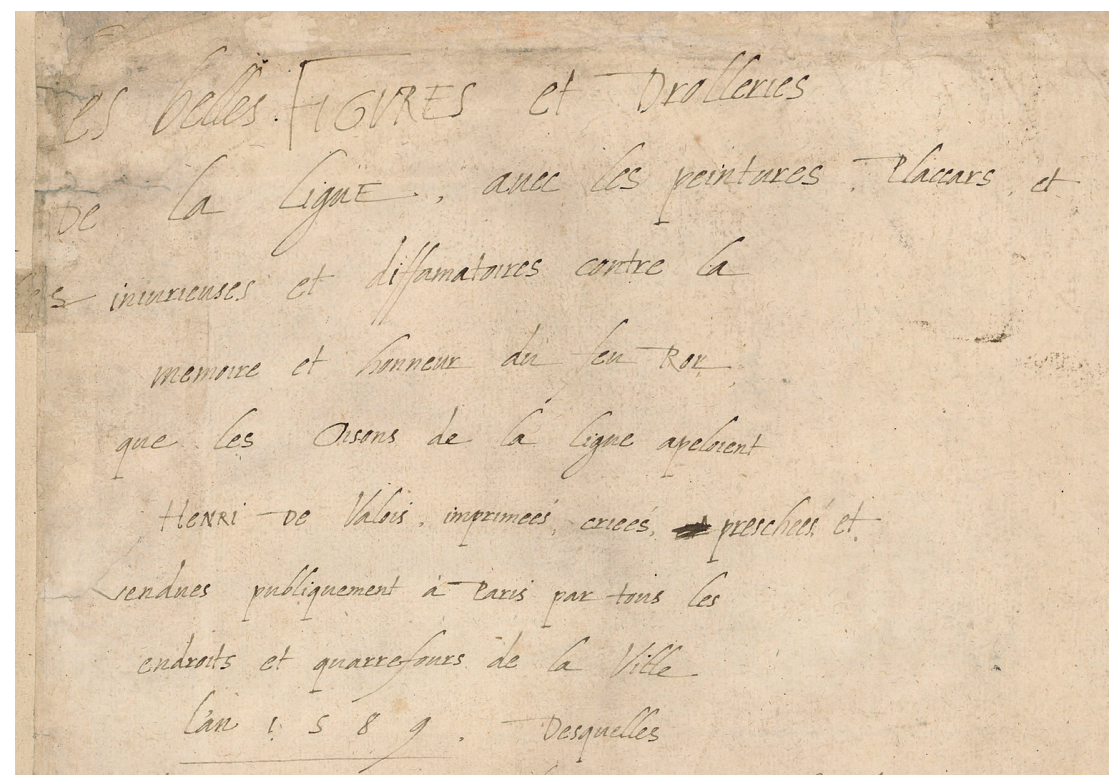

FIGURE 3 Pierre L'Estoile's scrapbook 'Les belles Figures et Drolleries de la Ligue' PARIS, BIBLIOTHÈQUE NATIONALE DE FRANCE, DÉPARTEMENT RÉSERVE DES LIVRES RARES, RES FOL-LA25-6, ORIGINAL FLYLEAF

and often by preserving many similarly rare items in a single place. ${ }^{28}$ Neil Harris' explanation of the Sammelband as a 'time capsule' most aptly sums up its historic value. ${ }^{29}$ The project Sammelband $15-16$, led by Malcolm Walsby and Katell Lavéant, is currently exploring the investigative value of the Sammelband as a cultural object. The example of the volume Les belles Figures et Drolleries de la Ligue from the library of Pierre L'Estoile is representative. The scrapbook gathers the remnants of the ephemeral pamphleteering culture dominating the Paris press in the 1580s and 1590s, arranged by context and themes, integrated with manuscript commentary by L'Estoile, and occasionally with handcoloured illustrations. ${ }^{30}$ The first page in the volume is also suggestive of the multiplicity of uses practiced for popular print items, as it indicates that these

28 An example of reader profiling is the focus of M. Rospocher, 'La miscellanea del cardinale. La battaglia della Polesella tra stampa, manoscritto e oralità', in: La invención de las noticias: las relaciones de sucesos entre la literatura y la información (Siglos XVI-XVIII), ed. G. Ciappelli \& V. Nider (Trento 2017), pp. 31-50.

29 N. Harris, 'La sopravvivenza del libro, ossia appunti per una lista della lavandaia', Ecdotica, 4 (2007), pp. 24-65.

30 Paris, BnF, RES FOL-LA25-6: Les belles Figures et Drolleries de la Ligue (available here: https://gallica.bnf.fr/ark:/12148/bpt6k859264h. 
scraps, preserved for the sake of posterity, had been 'printed, read out loud, preached and sold through all the streets and crossroads of Paris'. ${ }^{31}$

\section{The Bibliographic Census}

Whether we consider issues of production, distribution or consumption of pre-modern print, the traditional bibliographic census is a powerful and essential means for investigation. The examination of individual copies within a comparative perspective facilitates the identification of patterns and trends of consumption. The investigation of individual readers, following the trail of identifiable provenances, allows for a reconstruction of their reading practices and habits, contextualising popular print with other types of publications, and expressing reading practices within a cross-genre perspective. Other studies have focused on multiple copies of the same edition or text. Prominent examples include Conor Fahy's work on the 1532 Orlando furioso; the work by Neil Harris on the Orlando Innamorato; the long tradition of studies on Shakespeare's First Folio, which most recently includes the work by A.J. West and Emma Smith; Owen Gingerich's census of Copernicus' De Revolutionibus. ${ }^{32}$ Others have taken a broader approach by investigating titles within specific genres, such as Cristina Dondi's worldwide census of books of hours from fifteenth-century Italy, or the bibliographic investigation of early modern cookbooks. ${ }^{33}$ Many of these works are not specifically directed to investigating consumption, though naturally questions related to consumption surface through the comparative investigation of copies.

A bibliographic census may also offer indirect evidence of consumption. Patterns of production may be perceived as a strong indication of popularity (or unpopularity). Frequent editions of the same text, accompanied by low survival patterns, suggest that a book was printed often in response to high demand. In this context, counting bibliographic units is not enough, but it is essential to differentiate between separate issues or re-issues of printed material (an indication of poor or slow sales) as opposed to subsequent separate

31 Ibidem, upper flyleaf (unnumbered).

32 C. Fahy, L'Orlando furioso" del 1532: profilo di una edizione (Milan 1989); N. Harris, Bibliografia dell'« Orlando innamorato», 2 vols. (Modena 1988-1991); A.J. West, The Shakespeare First Folio: The History of the Book, 2 vols. (Oxford 2001-2003); E. Smith, Shakespeare's First Folio: Four Centuries of an Iconic Book (Oxford 2016); O. Gingerich, An Annotated Census of Copernicus' De revolutionibus (Nuremberg, 1543 and Basel, 1566) (Leiden 2002).

33 C. Dondi, Printed Books of Hours from Fifteenth-Century Italy: The Texts, the Books, and the Survival of a Long-Lasting Genre (Florence 2016); H. Notaker, Printed Cookbooks in Europe, 1470-1700: A Bibliography of Early Modern Culinary Literature (New Castle/Houten 2010). 
editions of a text. The production of chivalric novels by Michele Tramezzino in sixteenth-century Venice is a case in point. In her close analysis of the Frankfurt editions of Melusine, Ursula Rautenberg argued that the physical features of this popular book show a constant commitment to improving the reading experience and turning the main focus of a text from highbrow to lowbrow consumption. ${ }^{34}$ Auxiliary marketing strategies also offer useful, albeit indirect, indications of consumption practices. The study of newspapers advertisements can be used to identify lost books, as recently showcased in a study of over 6,ooo advertisements placed in Dutch newspapers (1620-1675) by Andrew Pettegree and Arthur der Weduwen. ${ }^{35}$

The bibliographic census as a form of investigation presents two main problems. Firstly, it tends to address texts that were and are part of the cultural canon. Many of the studies cited above testify to this trend. As such, the gathering of information related to the uses of the book is often treated as somewhat less important than the investigation of its production. The second problem is linked to the first, and is concerned with the survival of evidence. Canonical texts, even in relatively cheap editions intended for wide dissemination, often escaped total destruction in virtue of their cultural status. On the other hand, popular texts were used extensively and had a limited shelf-life, as many went in and out of fashion. As a result, they have very low survival rates. Issues of survival represent a substantial difficulty for the study of the production and distribution of popular print, yet even more so for the study of consumption. If it is true that what survives has escaped destruction by use, then what remains has, by definition, been used less or not at all. Yet it is through physical marks of use that we can decipher the activities of past readers.

\section{Consumption Documented}

The loss of ephemeral print is such that we only ever see fragments of what was originally produced. This is why the study of popular print in general, and in our case specifically of its uses, requires that direct evidence be supplemented with other sources to fill in the blanks. The study of consumption of popular print is not limited to library shelves but delves deep into the archive.

34 U. Rautenberg, 'New Books for a New Reading Public: Frankfurt "Melusine" Editions from the Press of Gülfferich, Han and Heirs', in: Specialist Markets in the Early Modern Book World, ed. R. Kirwan \& S. Mullins (Leiden 2015), pp. 85-109.

35 A. Pettegree \& A. der Weduwen, The Dutch Republic and the Birth of Modern Advertising (Leiden 2019); A. Pettegree \& A. der Weduwen, News, Business and Public Information: Advertisements and Announcements in Dutch and Flemish Newspapers, 1620-1675 (Leiden 2020). 
Library catalogues and book lists within probate inventories have traditionally been used as sources for the history of reading. Probate inventories offer the further advantage of locating the books within the household, thus offering insights into the material uses of the book. Entries vary in bibliographic detail, but when format and binding information are present, it is possible to profile the typology of books owned by individuals, as well as comparing them to other contemporary collections. In this as with other types of evidence, the study of popular print suffers from the intrinsic bias of the sources that represent it. As the objective of probate inventories was to determine the value of an estate for succession purposes, items that were deemed of negligible monetary value would be described with less detail. In the sixteenth century, cheap print may be described under collective entries, for example by the bundle. Whilst these indications were poor in detail, they are still useful to the profiling of a library, especially when we know how many items were included.

As time went on, lists of books within probate inventories became even less detailed, due to the increasing presence of books in private hands and their rising numbers, which made it less practical to produce complete listings. A study of nineteenth-century women readers in the Netherlands ascertained that only the most precious books were named, while the majority were described under generic indications, such as the number of bookshelves they occupied, and their overall appraised value. ${ }^{36}$ Our reliance on probate inventories for detailed information about book ownership, therefore, lessens in later centuries; though they remain invaluable sources to unveil the sociality of reading.

Dongelmans and De Vries also point out the social bias of probate inventories as sources: poorer social groups were less likely to have cumbersome successions that required the intervention of a notary. In that respect, the catalogues of circulating or lending libraries prove better sources, as they record the name of the borrower irrespective of their social status (although one still had to gain access to the service itself by way of paying a fee). New projects such as Books and Borrowing 1750-1830: An Analysis of Scottish Borrowers draw upon such evidence in the attempt to determine reading patterns for less visible readers. ${ }^{37}$ The probate inventories of book trade practitioners have also been used as indirect evidence of consumption, suggesting what books may be particularly popular, as in the case of the Krakow bookbinder Maciej Przywilcki

$36 \quad$ B. Dongelmans \& B. de Vries, 'Reading, Class and Gender: The Sources for Research on Nineteenth-Century Readers in the Netherlands', SPIEL, 19 (2000), pp. 56-88, esp. 65-6.

37 Books and Borrowing 1750-1830: An Analysis of Scottish Borrowers, PI: K. Halsey, Co-I: M. Sangster, funded by AHRC (202O-2023); details at https://gtr.ukri.org. 
or the bookseller Beatriz Pacheco in Santiago de Compostela. ${ }^{38}$ Ledgers offer more direct insights into individual customers' book buying habits, as in the case of Venetian bookseller Francesco de Madiis in fifteenth-century Venice or the lending booksellers Clays in eighteenth-century provincial England. ${ }^{39}$

Evidence also exists that documents the experience of reading first-hand; this very concept gave the title to The Reading Experience Database (RED) project. ${ }^{40}$ Letters, journals and other types of egodocuments offer exceptional insights into reading practices of the past, as they were often recorded in the 'here and now', which made the experience account all the more vivid. ${ }^{41}$ Yet even such sources have to be used with caution. Readers may not admit to the reading of chapbooks or other popular works, to others or even in documents meant for personal use, due to feelings of shame. Recollections of readings may be biased in other ways. For example, Matthew Grenby suggested that some accounts of childhood readings would appear to follow conventional patterns and ought not necessarily to be taken at face value. ${ }^{42}$

Prohibition or prescription had been part of the printing world almost since its inception, prompted by the fear that the widening of the reading public might lead to severe breaches of confessional boundaries and propriety. The creation of the Index Librorum Prohibitorum and the proliferation of prescribed readings lasted for centuries in the Catholic world - leading to the blanket ban of certain authors, of specific titles, or the censorship of selected passages. The Protestant world was not exempt from such measures; in eighteenth-century Denmark and Norway, the circulation of secular popular print was forbidden

38 J. Kiliańczyk-Zięba, 'The Book Inventory of the Sixteenth-Century Krakow Bookbinder, Maciej Przywilcki' and B. Rial Costas, 'The Inventory of Beatriz Pacheco's Bookshop (Santiago De Compostela, 1563)', in:Documenting the Early Modern Book World:Inventories and Catalogues in Manuscript and Print, ed. M. Walsby \& N. Constantinidou (Leiden 2013), pp. 261-82 and pp. 321-40 respectively. J.J. Kloek, 'Reconsidering the Reading Revolution: The Thesis of the 'Reading Revolution' and a Dutch Bookseller's Clientele around 180o', Poetics, 26 (1999), pp. 289-307.

39 C. Dondi \& N. Harris, 'Oil and Green Ginger: The Zornale of the Venetian Bookseller Francesco de Madiis, 1484-1488', in: Walsby \& Constantinidou (eds.), op. cit. (n. 38), pp. 341-406; J. Fergus, Provincial Readers in Eighteenth-Century England (Oxford 2006).

40 http://www.open.ac.uk/Arts/RED/index.html.

41 J. Blaak, Literacy in Everyday Life: Reading and Writing in Early Modern Dutch Diaries (Leiden 2009), pp. 32-7, contains a useful discussion of the use of egodocuments by historians.

42 M.O. Grenby, 'Before Children's Literature: Children, Chapbooks and Popular Culture in Early Modern Britain', in: Popular Children's Literature in Britain, ed. J. Briggs, D. Butts \& M.O. Grenby (2nd ed., London 2016), pp. 25-46, esp. pp. 37-8. See also J.A. Baggerman, 'The Infinite Universe of 18th Century Children's Literature', in: Childhood and Emotion: Across Cultures 1450-1800, ed. C. Jarzbowsky \& M. Safley (London 2014), pp. 106-21. 
in the northern areas, so to 'shield' the newly converted Saami population from dangerous deviations from orthodoxy. ${ }^{43}$ Other approaches from the Counter-Reformation, for example by Jesuit Antonio Possevino, were more constructive, such as lists of texts that were 'safe' to read. Both groups of such sources give hints as to what texts were read or meant to be read, how they were read, and by whom. However, these must be cross-referenced with sources that account for actual reading practices, as prohibition or prescription not necessarily mean compliance. A most successful source has been identified in the Inquisition Trials held at Cuenca, which are often explored to determine readership of cheap chivalric literature. ${ }^{44}$

Women were particularly affected by the restriction of reading practices. They are also more difficult to identify as readers due to the gendering of many of the sources considered. In probate inventories, for example, books were usually described under the possessions of the husband, and only rarely can one infer which titles were to be used by the family at large. In the later period, when periodicals or circulating libraries became available for direct access to the household, the head of the family still mediated access to texts, as subscriptions were in the man's name. Close reading practices have been employed as methodological frameworks in profiling women as readers. Julia Martins has suggested that even patterns in the underlining of a text may yield information about the reader's gender; some recipe books with reading marks limited to 'secrets of women' could conceal the reading practices of a midwife. ${ }^{45}$

Representations of readers, reading practices and the placing of print in social contexts also contribute to our understanding of the consumption of popular print. Even if we concede for a fictional or idealised element, artistic productions are still based on the observation of reality and offer important indications about such uses of print that are no longer represented even by surviving copies. Paintings such as The Peasant Wedding (1567) or The Fight between Carnival and Lent (1559) by Pieter Bruegel the Elder, where the focus is on everyday life scenes, show the material and social uses of popular print

43 E. Kleivane \& S. Óskarsdóttir, 'The Infant Jesus and his Mother in Late Mediaeval and Early Modern Scandinavian Book Culture', in: Languages in the Lutheran Reformation: Textual Networks and the Spread of Ideas, ed. M. Kauko, M. Norro, K.M. Nummila, T. Toropainen \& T. Fonsén (Amsterdam 2019), pp. 151-72, esp. p. 163.

44 See for example R. Prendergast, Reading, Writing, and Errant Subjects in Inquisitorial Spain (Farnham and Burlington 2011), p. 17; R. Chartier, 'Del libro a la lectura: Lectores "populares" en el Renacimiento', Bulletin hispanique, 99.1 (1997), pp. 309-24.

45 J. Martins, 'Understanding/Controlling the Female Body in Ten Recipes: Print and the Dissemination of Medical Knowledge about Women in the Early Sixteenth Century', in: Gender, Health, and Healing, 1250-1550 ed. S. Ritchey \& S. Strocchia (Amsterdam 2020), pp. $167-88$. 


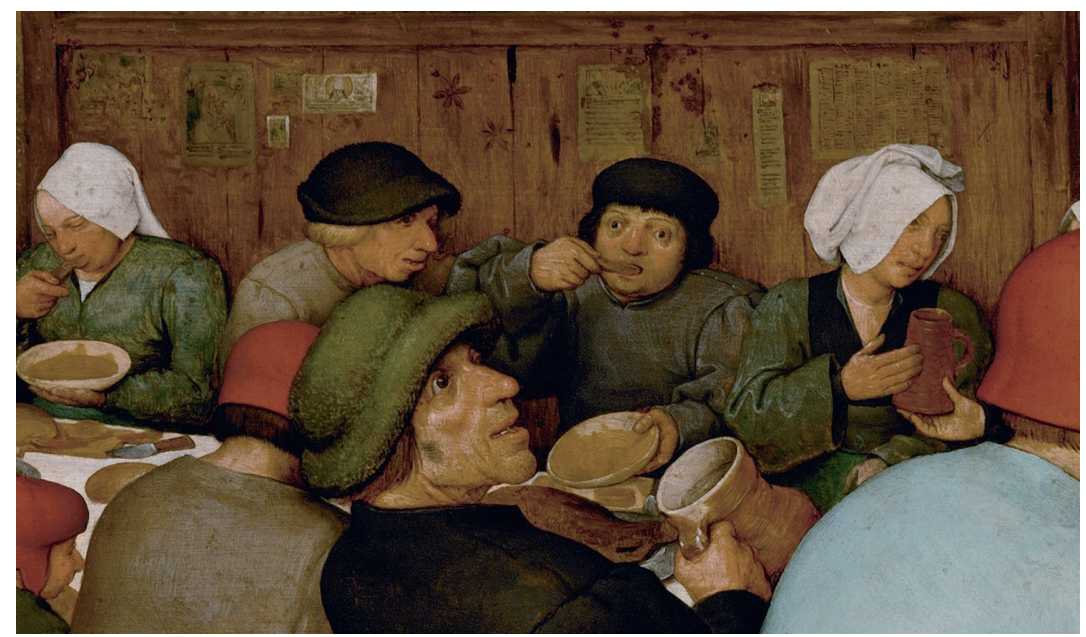

FIgURE 4 Pieter Bruegel the Elder, The Peasant Wedding (1567). Detail of chapbooks pasted on the wall

VIENNA, KUNSTHISTORISCHES MUSEUM. ACCESSED THROUGH WIKIMEDIA

within the public sphere. Representations of private reading are more common for later centuries; Lodovica Braida cited paintings by Chardin, Greuze, Fragonard, Liotard and Reynolds as examples of women readers in moments of relaxation. ${ }^{46}$ Similarly, literary texts like Jane Austen's Northanger Abbey, or Don Quixote give insights into popular genres such as gothic novels and chivalric romances, and practices of extensive reading - or even bibliomania. ${ }^{47}$ By exaggerating the impact of those texts on the fictional readers, authors tell us that their readers would have been acquainted with these reading trends either first-hand, or vicariously, and could therefore understand the satire.

The combination of these typologies of sources, within a comparative interpretive perspective, offers the possibility of gaining important insights into the cultures of consumption, transmission, and reception of popular print. The final section of this article is devoted to exploring selected patterns of use of popular print in early modern Europe across time and space.

46 L. Braida, 'Romanzi da leggere e da dimenticare: un'anomalia italiana del Settecento', $L a$ Bibliofilía, 119.3 (2017), pp. 431-51.

47 See for example J. Pearson, Women's Reading in Britain, 1750-1835: A Dangerous Recreation (Cambridge 1999), esp. 210-13; S. Malfatti, 'The Book-Reader Relationship in Golden-Age Spain: Reading Practices and the Publishing Industry in Don Quixote', in: A Maturing Market: The Iberian Book World in the First Half of the Seventeenth Century, ed. A.S. Wilkinson \& A. Ulla Lorenzo (Leiden 2017), pp. 87-100. 


\section{Patterns of Consumption}

\section{Literacy, Schooling, and Access to Print}

Popular print in the early modern age was approachable and affordable by readers of all ages and across the social divide - although, as noted by Natalie Zemon Davis, buying books might require to put off the purchase of everyday commodities of a more urgent nature, such as shoes. ${ }^{48}$ Accordingly, consumers of popular print are attested across social groups, age bands, and genders. Until children's literature became a standalone genre, subject to its own marketing strategies and occupying a separate section of the market, children were avid consumers of popular print such as chapbooks. ${ }^{49}$ Systematic surveys of corpora, for example of the French Bibliothèque Bleue, have allowed the identification of a very diverse reader-base for popular print materials, including several children. ${ }^{50}$

Schools catalysed access to popular print in several ways. Texts such as ABC s were ubiquitous across early modern Europe and formed the basis for elementary education, alongside other items such as hornbooks, primers, or the Italian Babuino. ${ }^{51}$ While there are examples of secular texts such as chivalric novels being used in vernacular schools, as discussed by Paul Grendler for Renaissance Italy, basic literacy acquisition was typically associated with the foundational teachings of the Christian faith. ${ }^{52}$ What is more, as Kate van Orden has demonstrated for sixteenth-century France, such elementary teachings were often associated with singing rather than reading - thus associating the acquisition of literacy with pre-existing aural knowledge on textual and musical grounds. ${ }^{53}$ This was perhaps a natural choice for religious reasons, but it also had an important pedagogical purpose, as it allowed pupils to associate the written word with texts and sounds that they had long since learnt through oral forms, thus significantly speeding up the learning process while making it easier for parents - in particular mothers - to support children's learning at home.

48 N. Zemon Davis, Society and Culture in Early Modern France (London 1975), p. 212.

49 M.O. Grenby, art. cit. (n. 42); L. Carnelos \& E. Marazzi, 'Children and Cheap Print from a Transnational Perspective', this issue, pp. 189-215.

$5^{\circ}$ M.D. Leclerc, 'Ex-libris manuscrits et notes dans les impressions de grande diffusion (XVII ${ }^{\mathrm{e}}-\mathrm{XIX}{ }^{\mathrm{e}}$ siècle)', Histoire et Civilisation du Livre, 2 (2006), pp. 323-45.

51 Carnelos \& Marazzi, art. cit. (n. 49).

$52 \quad$ P.F. Grendler, 'Schooling in Western Europe', Renaissance Quarterly, 43.4 (1990), pp. 77587; P.F. Grendler, 'What Zuanne Read in School: Vernacular Texts in Sixteenth Century Venetian Schools', The Sixteenth Century Journal, 13.1 (1982), pp. 41-54.

53 K. van Orden, 'Children's Voices: Singing and Literacy Sixteenth-Century France', Early Music History, 25 (2006), pp. 209-256, esp. p. 215. 
With the establishment of a more standardised school system, the younger generations often became more literate than their elders. In some regions, near-universal literacy was achieved through the eighteenth century. After a ruling in 1740 to regulate the schooling of children, a survey run by the Icelandic clergy in the 1780-9os confirmed that nearly everyone above the age of twelve could read. ${ }^{54}$ The majority of houses had at least prayer books and postils, religious texts being the main Icelandic printed output since the establishment of the press in the sixteenth century. ${ }^{55}$ As the press was strictly controlled by the religious authorities, popular texts of secular content were rather disseminated through manuscript copies. ${ }^{56}$ From the 178 os, however, ephemeral material, periodicals and popular literature became increasingly available in print. ${ }^{57}$ While Iceland was a unique case for literacy rates, child literacy continued to rise through most of Europe in the eighteenth and nineteenth century. This created a generational gap in several areas. It was not uncommon that children should read out loud to the rest of the family at night, making themselves the intermediaries between a text and its aural consumers.

Where the schooling systems were not well developed, religious congregations were often responsible for the rise in literacy and readership, fostering the consumption of cheap print for less literate groups. Some French sixteenth-century Protestant communities boasted relatively high literacy levels amongst women, to ensure that they were able to transmit the teachings of the catechism to their children. ${ }^{58}$ Catechetical schools supported the acquisition of basic literacy throughout the north of Italy from the second half of the sixteenth century. ${ }^{59}$ In the north of Norway, reading societies in rural areas in the nineteenth century were often linked to local parishes, providing access to print for farmers and fishermen who would hardly have been able to spend disposable income on books. ${ }^{60}$ Similarly, from the 1820 S Sunday school libraries

54 R.F. Tomasson, 'The Literacy of the Icelanders', Scandinavian Studies, 47.1 (1975), pp. 66-93, esp. p. 68.

55 The presence of cheap books in probate inventories remains a problem in this context; for the case of Italy, see A. Brundin, D. Howard \& M. Laven, The Sacred Home in Renaissance Italy (Oxford 2018), pp. 168-9, with further references.

$56 \quad$ Kleivane \& Óskarsdóttir, art. cit. (n. 43), p. 166.

57 H. Lárusson, 'Handwritten Journals in 19th- and Early 2oth-Century Iceland', in: Handwritten Newspapers: An Alternative Medium during the Early Modern and Modern Periods, ed. H. Droste \& K. Salmi-Niklander (Helsinki 2019), pp. 147-69.

58 Davis, op. cit. (n. 48), p. 82.

59 B. Benedict, 'I rudimenti per imparare l'italiano nel Cinquecento: il Salterio, il Babuino e l'Interrogatorio della Dottrina Cristiana', Verba, 35 (2008), pp. 425-37, esp. pp. 426-7.

6o E.S. Eide, 'Reading Societies and Lending Libraries in Nineteenth-Century Norway', Library \& Information History, 26.2 (2010), pp. 121-38, esp. pp. $126-7$. 
in Halifax and Huddersfield provided working-class children - boys and girls alike - with educational reading materials before the foundation of public libraries in the area. ${ }^{61}$ By the 182 os, the Sunday School Union had branches throughout England and had distributed over half a million books to children, mostly spelling books and catechisms. ${ }^{62}$ The vocation of Sunday school and parish libraries, of course, meant that most available content was represented by religious, devotional or moralistic popular print. Few titles could be considered as fiction or even entertainment more broadly; nonetheless, this bolstered the availability of easily accessible books and fostered literacy amongst traditionally illiterate groups.

As well as approaching devotional or moralising texts as part of their learning, all produced in enormous quantities by printers of popular matter, children had their own taste and interests in reading that far exceeded such provision. Schools directly supported a certain type of learning, however the social structure they provided also offered an important word-of-mouth element to the consumption of popular print. They may also offer an outlet for the distribution of books. For example, Jan Fergus reports that the Clay booksellers took daily orders at Rugby School in the eighteenth century. The boys' buying and borrowing patterns, documented by extensive ledgers devoted uniquely to business at the school, point to the clear popularity of certain texts, for example Frances Burney's Cecilia, a five-volume novel that was borrowed by nine boys over the course of six months, and most of all Goody-Two-Shoes. ${ }^{63}$

These and other occurrences (for example, purchases of titles such as Ladies Pocket Books, Ladies Memorandum Books, a Ladies Diary, and later the Lady's Magazine) are a strong indication of the gender-fluid reading interests of these boys. ${ }^{64}$ Fergus suggests that these readings represented a coping mechanisms against the hardships endured by the pupils at Rugby, and that the boys relished both a feminine touch and an element of escapism. ${ }^{65}$ Her findings mirror Jonathan Rose's discussion of the propensity of girls for adventure books such as Robinson Crusoe, David Copperfield or Ivanhoe in the late nineteenth and early twentieth century, which could have 'a liberating influence on their girl readers'.66 These studies stress the point that the consumption of popular print may not follow social prescriptions and intended readerships, and could

\footnotetext{
61 L.J. Parr, 'Sunday School Libraries in Halifax and Huddersfield before Public Libraries', Library \& Information History, 25.1 (2009), pp. 50-67.

62 Parr, art. cit. (n. 61), p. 52.

63 Fergus, op. cit. (n. 39), p. 120, pp. 139-41.

64 Fergus, op. cit. (n. 39), p. 15 o.

65 Fergus, op. cit. (n. 39), pp. 149-51.

66 Rose, op. cit. (n. 14), pp. 379-81.
} 
in fact foster imagination and flights of fancy, and include significant liberties on the part of readers. Similar observations on a larger and comparative scale would make a useful expansion of existing research, addressing the gendering (and cross-gendering) of reading practices across time and space.

\section{The Consumption of Popular Print within a Social Setting}

Small-scale social structures may catalyse access to print in a variety of settings. The recent study by Abigail Williams, The Social Life of Books, offers a taxonomy of access-points facilitated by trade and social structures and particularly within the eighteenth-century British home. ${ }^{67}$ In the case of news, for example, access may be offered to one's dependents within the early modern extended household. ${ }^{68}$ But the cohesive role of popular texts went well beyond access alone. The consumption of news was often a collective affair by nature, as portrayed by paintings such as Jan Steen's The Newsreader (c. 1665), showing one individual reading the news out loud, surrounded by a group of listeners. ${ }^{69}$

Several studies have highlighted a strong social component to the consumption of popular print. For the case of rural France in the sixteenth century, Natalie Zemon Davis discussed the cohesive role played by the veillée, an evening meeting where men, women and children gathered and mixed necessary chores with storytelling and reading aloud of popular tales. ${ }^{70}$ Similar practices are attested across pre-modern Europe. In nineteenth-century Ireland, for example, public wakes featured the reading out loud of folktales from miscellany manuscripts. ${ }^{71}$ The German equivalent of the Spinnstuben or spinning circles was inspired by a similar principle, and the same is documented for Iceland. ${ }^{72}$ In nineteenth-century Iceland, the wintereve gatherings were also an opportunity for education; children were taught their letters, and read out loud while adults carried out essential chores. ${ }^{73}$ Such activities reduced the separation between literate and illiterate, as all could gain access to texts, albeit in different forms and through different sensorial experiences. The fluctuation

67 A. Williams, The Social Life of Books: Reading Together in the Eighteenth-Century Home (New Haven 2018).

68 S. Webb \& P.H. Reid, 'Sir Francis Leicester's 'Good Library' at Nether Tabley', Library \& Information History, 34.1 (2018), pp. 1-22.

69 Foundation E.G. Bührle Collection, Zurich, oil on panel. Other examples in: M. van Groesen, 'Reading Newspapers in the Dutch Golden Age', Media History, 22.3-4 (2016), pp. 334-52.

70 Davis, op. cit. (n. 48), p. 201.

71 Vincent, op. cit. (n. 5), p. 93.

72 Vincent, op. cit. (n. 5), p. 94; Houston, op. cit. (n. 5), p. 248.

73 S.G. Magnússon, 'From Children's Point of View: Childhood in Nineteenth-Century Iceland', Journal of Social History, 29.2 (1995), pp. 295-323, esp p. 306. 
of textual forms such as folktales between print, manuscript, performance, and more broadly oral/aural transmission is symptomatic of similar practices.

A convivial approach to reading also served the all-important purpose of making time for books; as Christina Lupton has remarked for the case of eighteenth-century readers, the blurry boundaries between work and leisure often resulted in the sacrifice of reading time in favour of other activities. ${ }^{74}$ For rural areas, the preferred time for social events like the veillée was winter, as the long hours of light in the summer were reserved to work in the fields. In Iceland, handwritten newssheets were produced mainly in the winter months, as the brightest season was a time for intense agricultural work. Social meetings for the reading out loud of newssheets in the rural settlements took place mainly in the winter. ${ }^{75}$ In other settings, the workplace might allow some social reading. In the late nineteenth century, newspapers were the object of collective purchases and public reading in the workplace, to the extent that some individuals reported having learnt to read through these social occasions. This was the case for the handloom weaver William Farish in Carlisle. ${ }^{76}$ During the week, Sunday was traditionally reserved for devotional and biblical readings; but, as the working week extended to six days, these started to give way also to some secular readings.

The seasonality of reading has been explored in other contexts as evidence for social exchanges among readers, but also to signal the evolving role of books and reading in society. Bath was one of the few provincial centres in England to develop circulating libraries in the first half of the eighteenth century, whereas most other provincial locations remained somewhat behind. In the nineteenth century, Blackpool became a standard setting for popular publications such as seaside adventures, and Christmas annuals became a staple of Victorian culture. ${ }^{77}$ Fostered by the rise of seasonal travel and leisure, seasonal readings were supported by their own trends of production, marketing and advertisement campaigns. The rise of summer reading, investigated by Donna Harrington-Lueker for the nineteenth-century United States, is a case in point. ${ }^{78}$ Similar trends of seasonal holiday readings also started to emerge in Europe - though, as far as I know, no systematic study exists of these practices.

\footnotetext{
74 C. Lupton, Reading and the Making of Time in the Eighteenth Century (Baltimore 2018), p. 35 .

75 Lárusson, art. cit. (n. 57), p. 157.

76 Vincent, op. cit. (n. 5), p. 95.

77 M. Beetham, "'Oh! I Do Like to Be Beside the Seaside!": Lancashire Seaside Publications', Victorian Periodicals Review, 42.1 (2009), pp. 24-36.

78 D. Harrington-Lueker, Books for Idle Hours: Nineteenth-Century Publishing and the Rise of Summer Reading (Amherst 2018).
} 
The sociality of reading soon took the form of structured groups and rituals. Abigail Williams discussed reading practices by the wealthier groups in Britain as regulated by social conventions and as an important part of social exchanges. ${ }^{79}$ The rise of reading societies, lending and circulating libraries has been linked to the rise of literacy levels everywhere in Europe, though these were often very uneven in terms of inclusivity. Reading societies and the first lending libraries in Norway's urban areas generally catered for the more affluent groups of society, such as merchants, apothecaries or shopkeepers, but they certainly provided access to popular literature such as novels as part of their holdings. ${ }^{80}$ While titles initially on offer, including novels in foreign languages, markedly indicate an elite readership, the rising numbers of popular print titles offered by lending libraries from the 1810 s suggest that they were opening up to a more diverse reading public. This corresponded to a gradual loss of foreign-language texts, which disappeared almost entirely by the $1850 \mathrm{os}{ }^{81} \mathrm{In}$ the north of Europe in particular, reading societies have also been linked to the bottom-up application of technical innovations, catalysing societal and economic change. ${ }^{82}$ In the eighteenth and nineteenth century, agricultural societies often held a small library that could be perused by local farmers; examples from Scotland and Norway have been argued to be directly linked to technical improvement impacting society as a whole. ${ }^{83}$

\section{Between Restriction and Emancipation}

As discussed, a social element to reading practices did not necessarily reflect inclusivity. Clubs and reading societies continued to foster an elite readership well into the nineteenth century. In the Low Countries, for example, book clubs explicitly banned women from participating in the early nineteenth century. ${ }^{84}$ Social restrictions were similarly reflected in curtailed access to reading materials. What women should or should not read was a topic of regular concern throughout the pre-modern age. Some categories of popular

\footnotetext{
79 Williams, op. cit. (n. 67).

8 o Eide, art. cit. (n. 6o), p. 123 .

81 Eide, art. cit. (n. 6o), p. 132.

82 R. Bowd, 'Useful Knowledge or Polite Learning? A Reappraisal of Approaches to Subscription Library History', Library \& Information History, 29.3 (2013), pp. 182-95.

83 M. Towsey, "Store their Minds with Much Valuable Knowledge': Agricultural Improvement at the Selkirk Subscription Library, 1799-1814', Journal for Eighteenth-Century Studies, 38.4 (2015), pp. 569-84; Eide, art. cit. (n. 6o).

84 A. Lubbers, 'The Republic of Readers: Book Clubs in the United Kingdom of the Netherlands, 1815-183o', in: Plotting the Reading Experience: Theory/Practice/Politics, ed. P.M. Rothbauer, K.I. Skjerdingstad, L. McKechnie \& K. Oterholm (Waterloo, Ontario 2016), pp. 343-6o.
} 
print were often frowned upon, and in the case of entertainment literature, may be seen as entirely inappropriate for women. Juan Luis Vives voiced his concern explicitly in his De institutione foeminae christianae (1523) and again in his De officio mariti (1529), giving explicit instructions as to how a husband and father was to watch over his wife and children, with particular emphasis over their reading habits. ${ }^{85} \mathrm{He}$ included a list of popular novels that must at all cost be avoided, taking an international perspective by way of including popular titles originally from Spain, France and Flanders. Among the titles listed were Amadis, Tirant lo Blanc, Celestina, Paris and Viena, Carcel d'Amor, Maguelonne, Melusine, Splandiano and several others among the great bestsellers of the time.

Women's restrictions in their access to print are also visible in close-reading interpretations of books. Jennifer Richards has explored the gender-bias in the use of a text such as The Womans Booke in early modern England, identifying reactions of shame and self-censorship on the part of male readers, who were still the only ones who seem to have annotated copies of the book. The minority of documented female readers may sign their copies, but refrained from annotating them, and in one case the statement of ownership was given 'teste marito', with permission from the owner's husband. ${ }^{86}$

In the age of the novel, pictorial representations of women readers made many a statement about the appropriateness of readings. While many depictions of silent reading in the eighteenth and nineteenth century include one or more young women occupied with small books - possibly edifying novels, or devotional texts, and yellow-backs - several others portray dishevelled or unclothed female readers dedicating themselves to objectionable texts. ${ }^{87}$ Many such paintings contain overt or hinted sexuality, suggesting a weakening of moral awareness, and even diabolic temptation.

Despite the weight of social conventions, women 'found ways of resisting attempts to control them, as they negotiated their own reading space in a world frequently hostile to their intellectual freedom'. ${ }^{88}$ From the nineteenth century, new types of ephemeral print such as magazines had the effect of facilitating the creation of new communities of readers, in which women as both readers and authors were key agents in their own emancipation as well

85 J.L. Vives, De Institutione Feminae Christianae, Liber Primus, ed. C. Fantazzi \& C. Matheeussen (Leiden 1996), pp. 44-7.

86 J. Richards, 'Reading and Hearing The Womans Booke in Early Modern England', Bulletin of the History of Medicine, 89.3 (2015), pp. 434-62.

87 K. Brown, Women Readers in French Painting 1870-1890: A Space for the Imagination (Farnham 2012), dedicates a full chapter to 'books and bodies'.

88 M. Lyons, Readers and Society in Nineteenth-Century France: Workers, Women, Peasants (Basingstoke and New York 2001), p. 100. 


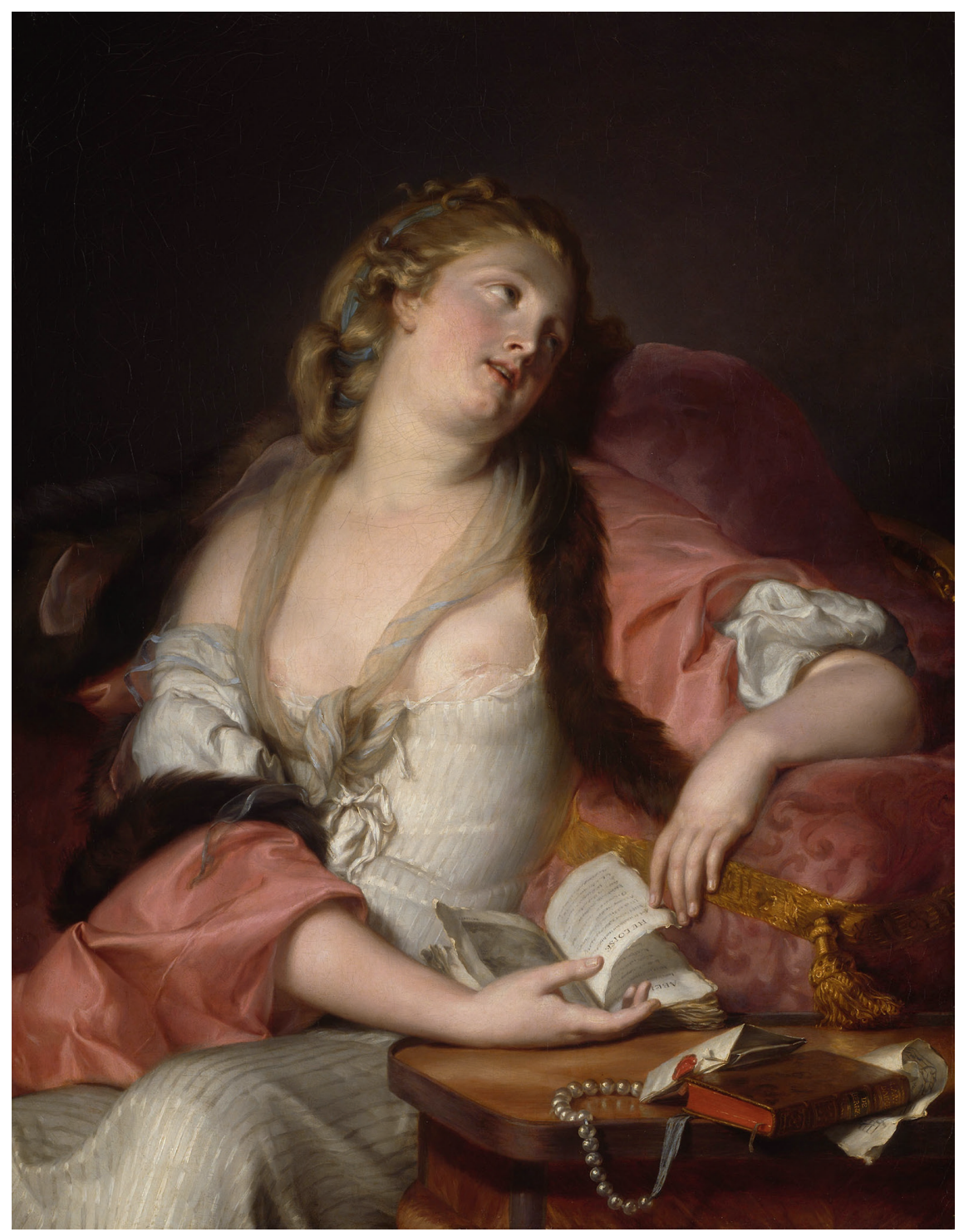

FIGURE 5 Auguste Bernard d'Agesci, Lady Reading the Letters of Heloise and Abelard. c. 1780 CHICAGO, ART INSTITUTE OF CHICAgO, EUROPEAN PAINTING AND SCULPTURE, GALLERY 216. OIL ON CANVAS

as more generally contributing to the European intellectual landscape. The collaborative project Travelling Texts, 1790-1914: The Transnational Reception of Women's Writing at the Fringes of Europe, led by Henriette Partzsch, has explored the circulation and popularity of female authors in the nineteenth 
century. ${ }^{89}$ Fredrika Bremer, widely translated in the north of Europe, and from France disseminated into Spain, is one example of the textual patterns uncovered by the collaborative efforts of Travelling Texts..$^{90}$

Different studies concur that books and reading played an essential part in establishing roles in modern society and as catalysts of societal change. Building upon earlier studies such as Neil Postman's Disappearance of Childhood, Edel Lamb suggested that 'textual cultures produce concepts of childhood' - in other words, that the efforts of the printing industry in imagining and identifying the child reader contributed to shaping the expected role of children in society. ${ }^{91}$ Lodovica Braida discussed how proto theorists of reading in the eighteenth century such as Giuseppe Maria Galanti identified the importance of novels as highly relevant to the ethical and sentimental education of women, and therefore playing an essential role in society. ${ }^{92}$ Starting from this perspective, some decades later Giuseppe Compagnoni also praised the suitability of entertainment literature as an ideal instrument of social construction, precisely because of its appeal and light-heartedness. In his view, this made novels directly related to female emancipation. A general disregard of the Italian literary milieu for literature of wide dissemination meant that almost all novels read in Italy in the eighteenth century - with the illustrious exception of the abbot Pietro Chiari - were translations of English and French works. It would be interesting to put this trend in correlation with later societal movements as a way of verifying Compagnoni's claim of the relevance of popular literature beyond its immediate uses.

\section{Materialities of Consumption}

Reading required a number of material circumstances; many early modern paintings representing readers portray their subjects by a window or by a lamp, undoubtedly for aesthetic and symbolic reasons, but also because direct light was an ideal condition for reading. The obvious need for light explains why places such as inns and taverns have been traditionally linked with the consumption of popular print. In early modern Iceland, light and fuel were so expensive that the night quarters of the home were normally dark, which

89 Travelling Texts, 1790-1914: The Transnational Reception of Women's Writing at the Fringes of Europe, PI: Henriette Partzsch: https://travellingtexts.huygens.knaw.nl.

9o H. Partzsch, 'The Complex Routes of Travelling Texts: Fredrika Bremer's Reception in Nineteenth-Century Spain and the Transnational Dimension of Literary History', Comparative Critical Studies, 11.2-3 (2014), pp. 281-93.

91 E. Lamb, Reading Children in Early Modern Culture (Cham 2018), p. 5.

92 Braida, art. cit. (n. 46). 
made the head of the household also the gatekeeper of reading practices. ${ }^{93}$ The sociability of reading also supplied an alternative for those with failing eyesight. Spectacles only became widely used from the eighteenth century, meaning that before then those with challenged vision may only be able to access books by relying upon others. ${ }^{94}$

The materiality of books themselves may also be suggestive of their expected uses. Small formats were explicitly intended as catalysts of a broader dissemination. Being appropriate for wider patterns of use, pocketsize books effectively expanded the time available for reading. This was well understood and used in support of the marketability of books. A small format edition of Luis de Granada in eighteenth-century Spain was produced so that the smaller volumes 'could be carried in a bag, in the carriage, to the countryside, so that devotion may accompany leisure time. ${ }^{95}$ Output and distribution may in themselves suggest the time of consumption; the circulation of books through the railway networks explored by Francesca Tancini for nineteenth-century England and France is a good example. ${ }^{96}$ Paintings dating from the Industrial Revolution, such as Augustus Egg's Travelling companions (1862) show individuals reading pocketsize books or newspapers while travelling by rail. ${ }^{97}$ The rise of the railways would lead to the dissemination of kiosks everywhere in Europe, starting in 1848 with W.H. Smith in London's Euston Station. ${ }^{98}$ The Hispanic novela de quiosco, developed in the early twentieth century, will be a legacy of the same concept. ${ }^{99}$ The periodic element (the expressions 'El Cuento Semanal' and 'La Novela de Hoy' were also in use) became associated also with the new means of distribution. ${ }^{100}$

The form of serialised and abridged texts is also indicative of the expected wider audience compared to the bulky original text. This is the case with abridgements aimed at children (as discussed by Carnelos and Marazzi, Gomis

93 Lárusson, art. cit. (n. 57), p. $15^{2}$.

94 Williams, op. cit. (n. 67), pp. 68-9.

95 A. Castillo Gomez, 'Testi di larga circolazione in Spagna tra antico regime ed età contemporanea', in: Libri per tutti. Generi editoriali di larga circolazione tra antico regime ed età contemporanea, ed. L. Braida \& M. Infelise (Milan 2010), pp. 293-310, esp. pp. 301-2.

96 F. Tancini, 'The Railway Library and Other Literary Rubbish that Travels by the Rail', in: Rospocher, Salman \& Salmi (eds.), op. cit. (n. 26), pp. 71-88.

97 Birmingham Museum and Art Gallery, oil on canvas, 1862. Accessed through Wikimedia.

98 F. Tancini, 'Libri di gran classe alla fermata del treno: L'altra faccia degli Illustrators of the Eighteen-Sixties', L'Illustrazione, 2.2 (2018), pp. 47-64, esp. p. 49.

99 R. Sánchez García, 'Diversas formas para nuevos públicos', in: Historia de la edición en España (1836-1936), ed. J.A. Martínez Martín (Madrid 2001), pp. 241-68, for a comprehensive view and further references.

100 Sánchez-Garcia, art. cit. (n. 99), pp. 251-3. 
and Salman in this volume) or dialect readers. The thinner appearance of novels' serialised instalments served multiple purposes in encouraging consumption. If the purchase of a novel outright might seem daunting for its length and cost, the staggered purchase of instalments circumvented both problems. Their serialisation, meanwhile, by using cliff-hangers as narrative devices, fostered a relationship with readers who were eager to find out how the story developed. Instalments could be swapped around among friends; a good feuilleton would then be cut from the magazine or newspaper and sewn together to form a proper book. ${ }^{101}$ This became a lucrative market throughout Europe, subject to much higher print run figures than most books that were published as such from the start. ${ }^{102}$

Whilst form is only one of many clues for past uses of print, the materiality of texts dictated their possible uses, and it remains suggestive of past consumption. Performative texts, such as ballads, may retain important clues both to their intended uses and their audiences. For sixteenth-century Germany, Amelie Roper has discussed various examples of ephemeral musical materials that are suggestive of their uses. ${ }^{103}$ A typology of broadsides aimed at the musical elite featured the polyphonic score arranged in such a way so that the music could be performed by individuals positioned at the four sides of a table. ${ }^{104}$ But it is the absence of the score, Roper argued, that is suggestive of wider dissemination. A series of poorly printed single-sheet items, containing the text of a ballad or song, were furnished with a paper label indicating the traditional tune that ought to be sung with the text. ${ }^{105}$ Using a new text with an old tune ('contrafactum') was a standard practice to allow for wider access to printed music; this was even more effective in song pamphlets that offered a choice of tunes that could be used, meaning that consumers who did not know one tune may still be able to rely on another. ${ }^{106}$ Such trends in production created patterns of intertextuality across early modern songs, intertwining meanings and performance.

\footnotetext{
101 Lyons, op. cit. (n. 88), pp. 117-18.

102 Castillo Gomez, art. cit. (n. 95), p. 302.

103 A. Roper, 'German Music Broadsheets, 1500 to 1550: Production, Persuasion and Performance', in: Broadsheets. Single-Sheet Publishing in the First Age of Print, ed. A. Pettegree (Leiden 2017), pp. 400-41, and A. Roper, 'Poor Man's Music? The Production of Song Pamphlets and Broadsheets in Sixteenth-Century Augsburg', in: Kirwan \& Mullins (eds.), op. cit. (n. 53), pp. 175-98.

104 Roper, art. cit. (n. 103: 2017), pp. 425-6.

105 Roper, art. cit. (n. 103: 2017), pp. 411-13.

106 Roper, art. cit. (n. 103: 2015), pp. 184-7 and pp. 194-5.
} 
The study of early modern almanacs has also offered a useful investigative model for the association of form and uses. Lodovica Braida pointed out that the increasing allowance of white space allowed for the emerging habit of

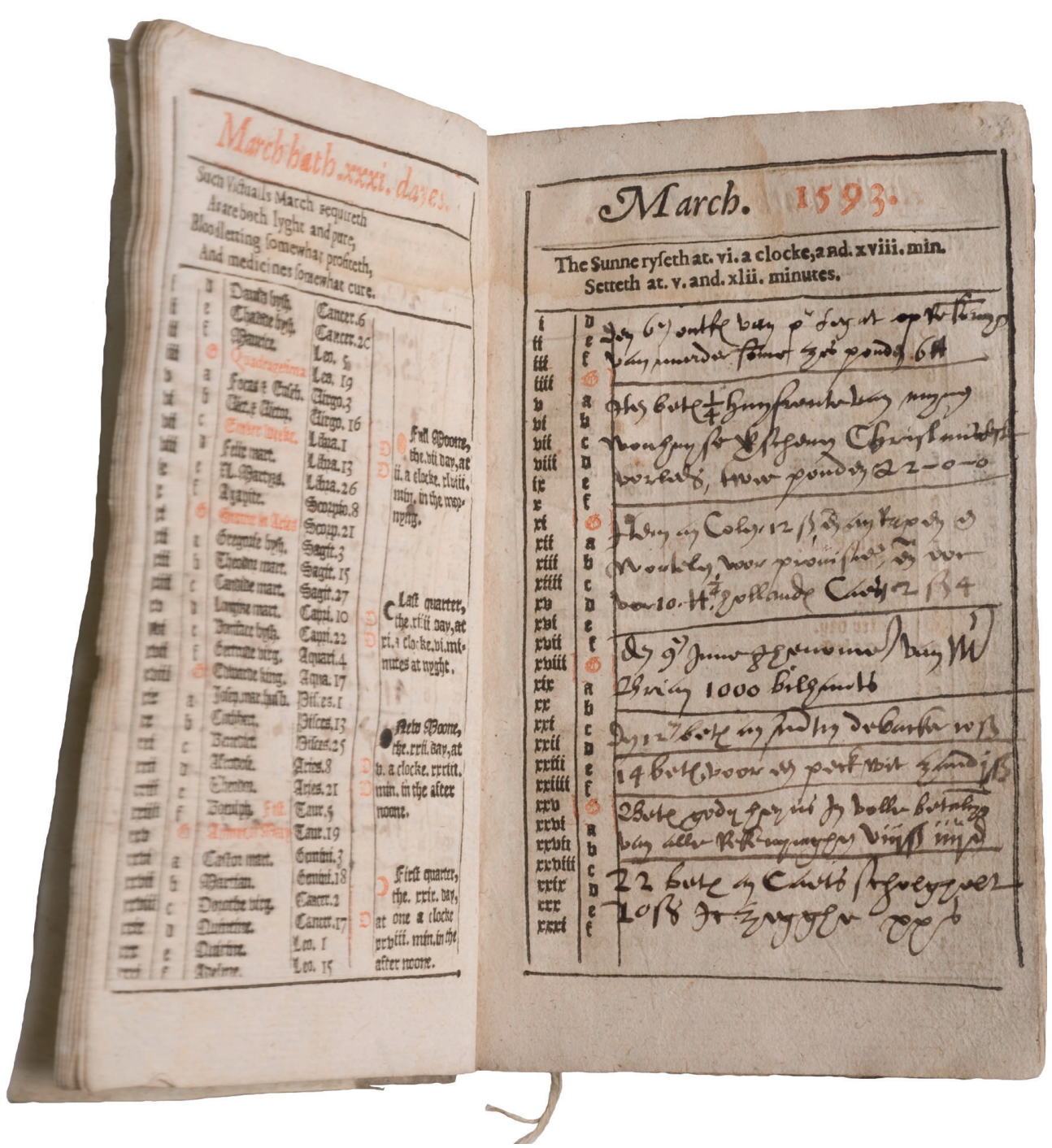

FIGURE 6 Annotated almanac (1593)

A new almanacke and prognostication, seruing for the yeere of our Lorde God. M.D. XCIII.: Composed according to lawfull and lawdable art, and referred specially to the meridian and eleuation of the northeren pole of Canterburie, but may serue vniuersally, without any great error, for most partes of Englande.

WELlCOME COLlECtion. ATtRibution 4.0 international (CC By 4.0) 
annotating and customising such texts. ${ }^{107}$ The example reproduced shows how these items were meant to be used. While not all almanacs were necessarily annotated, their form anticipated that readers may wish to do so. Textual forms may also hint to levels of literacy, with oral forms adopted to ease the reading process, as posited by Elisa Marazzi in her study of the Italian Barbanera almanacs. ${ }^{108}$ In the Low Countries, small-format almanacs were supplemented with plug-on texts of the same size, such as jestbooks, songbooks or chronicles - not very different, in fact, from today's Filofax (which, ironically, is not cheap). This modular approach to the production of popular print was designed to meet the specific requirements of each reader with the smallest investment on the part of the printer or publisher. ${ }^{109}$ In terms of consumption, this meant that different typologies of popular texts were merged together into one physical book, and the use of one may well catalyse the use of the other.

\section{Popular Print as a Cross-Sensory and Intermedial Experience}

The consumption of popular print was not only governed by the crossing of time and space, but also of media. The consumption of recipe books, for example, often featured the cross-contamination of different sources, both written and oral, with the integration, correction, or validation of recipes by hand. ${ }^{110}$ As well as single-reader uses, such patterns are also found as long family traditions, indicating that the recipe books were passed on from one generation to the other. ${ }^{111}$ Some women readers also liked to transfer their annotations into manuscript notebooks instead, with these items becoming an intrinsic part of their library. ${ }^{112}$

Other genres were also subject to similar trends. The consumption of news and cheap occasional publications has been explored as a field where media boundaries were particularly loose; studies by Nina Lamal and Alexandra Schäfer among others have demonstrated the fluidity and combination of

107 L. Braida, 'Dall'almanacco all'agenda: Lo spazio per le osservazioni del lettore nelle guide del tempo italiane (XVIII-XIX secoli)', ACME, 41.3 (1998), pp. 137-67.

108 E. Marazzi, Sotto il segno di Barbanera: Continuità e trasformazioni di un almanacco tra XVIII e XXI secolo (Milan 2017), p. 19.

109 See J. Salman, 'Information, éducation et distraction dans les almanachs hollandais au XVIIIe siècle', in: Les lectures du peuple en Europe et dans les Amériques du XVII ${ }^{e}$ au $X X^{e}$ siècle, ed. H.-J. Lüsebrink, Y.-G. Mix, J.Y. Mollier \& P. Sorel (Paris 2003), pp. 49-58.

110 Examples discussed in Reading and Writing Recipe Books, 1550-1800, ed. M. DiMeo \& S. Pennell (Manchester 2013).

111 See for example M. Shanahan, Manuscript Recipe Books as Archaeological Objects: Text and Food in the Early Modern World (Lanham 2015).

112 E. Leong, "Herbals she Peruseth": Reading Medicine in Early Modern England, Renaissance Studies, 28.4 (2014), pp. 556-78. 
media in collections of local or national news. ${ }^{113}$ The consumption of entertainment popular print underwent similar inter-medial patterns, with systematic mechanisms of cross-fertilisation between print and oral culture. Printers like Niccolò Zoppino engaged with both the production of the printed word, and an oral output embedded in the street culture of Renaissance Venice. The fluidity of textual forms across the genres of entertainment literature and news in Renaissance Italy (for example, the fact that both employed the canzone, or song) is due also to the fact that the same individuals may be active in disseminating both. ${ }^{114}$ The work by Massimo Rospocher and Rosa Salzberg has demonstrated that Zoppino's outputs within the sphere of oral communication was in itself a publishing strategy, and catalysed the circulation and reception of cheap print. The consumption of print was complemented by an endemic exposure to oral traditions. Textual traditions known under denominations such as the Gobbo di Rialto in Venice or Pasquino in Rome (and the derivative category of pasquinades) can only be understood if framed within the broader context of a pan-mediatic transmission and reception, of which much is hidden from sight.

The iconographic element was also extremely important, as images provided an additional, more inclusive point of access into the textual content. Pasquinades were often accompanied by caricatures and hostile drawings produced anonymously, with the explicit function of being viewed and understood by as many passers-by as possible. ${ }^{115}$ Illustrated genres were also widely available in provincial areas; Jean-Pierre Seguin's studies on French canards demonstrate the extensive uses of illustrations in news related to monstrous births, supernatural events and natural disasters. ${ }^{116}$ The rise of children's literature in the eighteenth and nineteenth centuries was also accompanied by the increasing presence of illustrations. ${ }^{117}$ In addition to the iconographic element, the use of colour was also a catalyst for major cultural and social changes in

113 A. Schäfer, 'The Acquisition and Handling of News on the French Wars of Religion: The Case of Hermann Weinsberg', in: News Networks in Early Modern Europe, ed. J. Raymond \& N. Moxham (Leiden 2016), pp. 695-715. N. Lamal, Fwo-funded project: 'Old vs. New Media: Handwritten Newsletters in the First Age of the Printed Newspaper' (2017-2020).

114 See the special issue of The Italianist, 34.3 (2014), 'Oral Culture in Early Modern Italy: Performance, Language, Religion'.

115 Castillo Gomez, art. cit. (n. 8), pp. 88-9.

116 J.P. Seguin, L'Information en France avant le périodique: 517 canards imprimés entre 1529 et ${ }_{1631}$ (Paris 1964).

117 Carnelos \& Marazzi, art. cit. (n. 49). 
the nineteenth century; the first systematic study on this is currently being undertaken by Francesca Tancini. 118

As well as accompanying text, images were also (perhaps mostly) employed as standalone conveyors of information throughout the early modern age, both as cheap and expensive print. Professional cartoonists, engravers and painters were active throughout Europe, and their output was reproduced in the tens of thousands. ${ }^{119}$ The case of the St Christopher, the first surviving object known to have been printed in Europe, is exceptional as a cultural milestone but far from unique. Images continued to be consumed alongside text, with shops stocking devotional images by the hundreds and often thousands, hinting at a consumer-base significantly higher than the readership of most books.

Early modern Europe was far more at ease with images than with the written word, as the base meanings of images were accessible to all. Block books were produced well before printing with movable types and continued to circulate alongside hand-printed books. Examples such as the 1470 Ars memorandi per figuras Evangelistarum show how iconography was used as a form of narrative to memorise the core contents of the New Testament. ${ }^{120}$ Through the portrayal of the tetramorph, each based around the symbol of the evangelists, four large woodcuts reminded the beholders of the key episodes of the gospels. The same function, of course, had long being fulfilled by stained glass windows, mural and roof paintings in churches; through such items, popular print gave the ability to meditate the gospels at home, relying on traditional memorisation techniques to support the transmission of knowledge irrespective of literacy levels.

\section{Concluding Remarks and Avenues for Further Investigation}

The study of the consumption of popular print offers important insights into the more neglected groups of European pre-modern readership, as well as offering a cross section of the most widely disseminated genres and practices across society. Related reading practices were less visible than most, due to poor survival and a general bias in the preservation of sources. Nonetheless, what does survive indicates that popular print favoured and incentivised a general

118 F. Tancini, PiCoBoo - 19th-Century European Picture-Books in Colour (Newcastle University); https://www.picoboo.eu. Some early results are discussed in Tancini, art. cit. (n. 98 ).

119 Burke, op. cit. (n. 5), pp. 92-3.

120 M. Gabriele (ed.), L'arte della memoria per figure: con il fac-simile dell'Ars memorandi notabilis per figuras evangelistarum (1470) (Lavis 2006). 


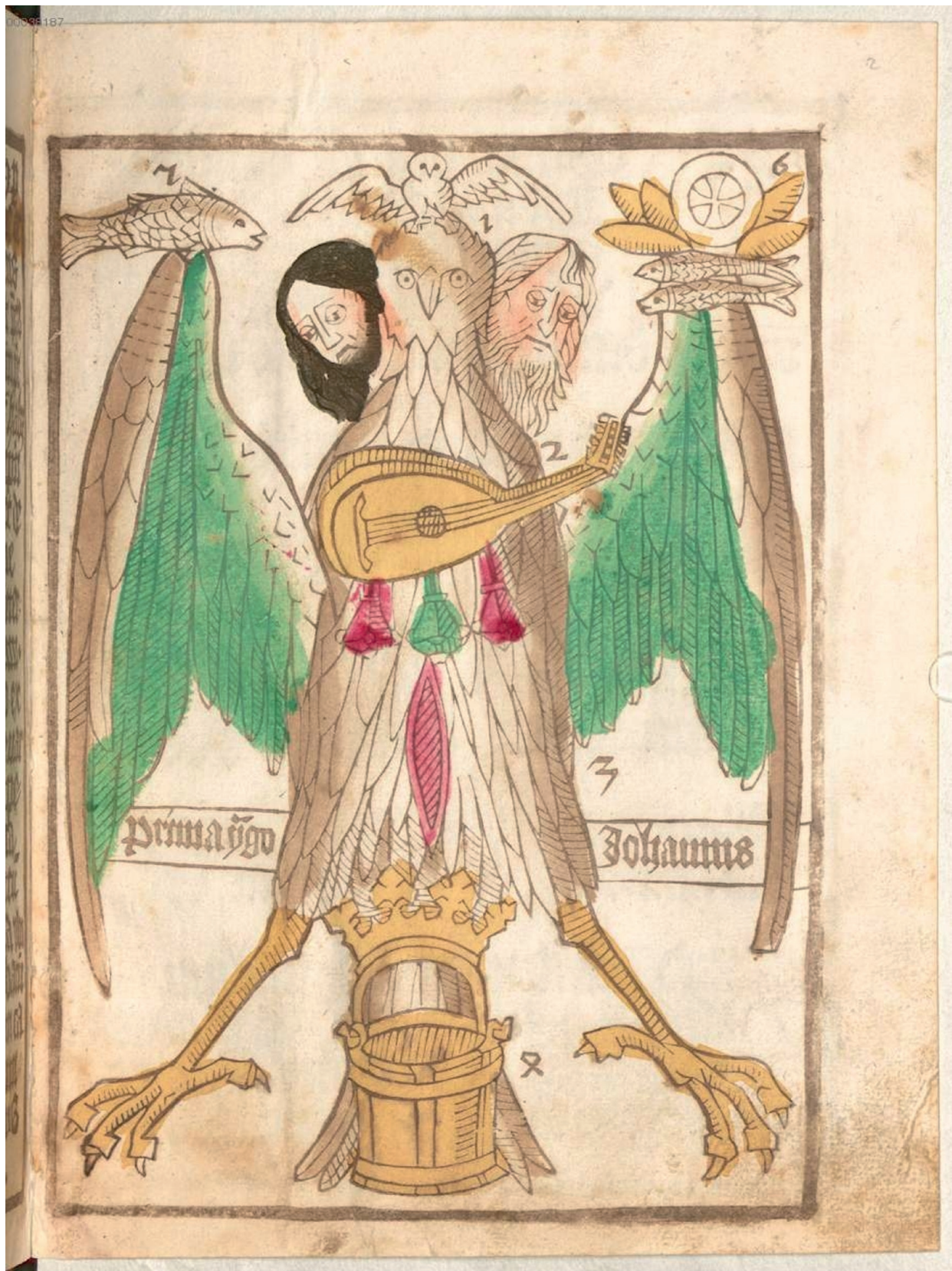

FIGURE 7 Ars memorandi per figuras: between text and image Ars memorandi notabilis $p$ [er] figuras ewangelistar [um]

([South of Germany, 1470]) MUNICH, BAYERISCHE STAATSBIBLIOTHEK, XYLOGR. 10. URN:NBN:DE:BVB:12-BSB00038187-4 
retention of literacy, as well as granting permanence to languages of lesser diffusion, thus playing a far more important role for European culture than its modest appearance would suggest. ${ }^{121}$ A comparative study of these sources and their uses, considering well-trodden areas alongside the peripheries of early modern Europe through a coherent investigative focus, is much needed.

Revivalist movements, such as the pan-European recording of traditional folklore in the nineteenth century, have been identified as foundational factors in the rise of nationalisms as a by-product of the development of national identities. ${ }^{122}$ The comparative study of popular textual forms such as fairy tales, for example, shows that far from being separate, written folklore traditions reveal a shared heritage - albeit with variations according to taste and the localisation of texts. ${ }^{123}$ As part of the EDPOP activities, Rita Schlusemann has led a group effort in identifying long-lived textual traditions that have enjoyed a wide European fortune; articles in this special issue offer some conclusions on that topic that I will not anticipate here. ${ }^{124}$ Projects such as Travelling Texts have uncovered similar dynamics, stressing the importance of a comparative and transnational approach. These studies show that audiences across Europe were familiar with the same texts, whose popularity was facilitated through extensive translation and borrowings across 'monolingual' cultures. Despite the demonstrated relationship between the rising nationalisms and popular culture, an in-depth study of these materials sheds light on the shared roots of Europe - and indeed, further ashore. In other words, it was not just the Republic of Letters that shared knowledge without borders; popular print was subject to similar trends, albeit without the benefit of a lingua franca that would make these similarities evident to all, either then or now.

Future research plans will benefit from a sustained dialogue with other research projects and networks where similar transnational patterns for the circulation of texts across borders have been ascertained. A comparative study of translation practices and enduring popularity would offer additional access points to our understanding of the shared European dimension of popular print.

121 R.A. Houston, "Lesser-Used' Languages in Historic Europe: Models of Change from the 16th to the 19th Centuries', European Review, 11.3 (2003), pp. 299-324, esp. pp. 301-2.

122 Burke, op. cit. (n. 5), ch. 1.

123 S. da Silva \& J.J. Tehrani, 'Comparative Phylogenetic Analyses Uncover the Ancient Roots of Indo-European Folktales', Royal Society Open Science, 3.1 (2016).

124 R. Schlusemann, 'A Canon of Popular Narratives in Six European Languages between 1470 and 1900: The "Griseldis"-Tradition in German and Dutch', in: Rospocher, Salman \& Salmi (eds.), op. cit. (n. 26 ), pp. $265^{-85}$. 